\title{
The Spanish Tragedy Redux
}

\author{
Dianne M. Hunter ${ }^{1}$ \\ Trinity College, Connecticut, USA
}

\begin{abstract}
A hybrid of family history and literary criticism combining academic analysis and research with memoir, this essay argues that an object-relations concept of transmission of turbulence illuminates the phantom structure of Thomas Kyd's Elizabethan metatheatrical play The Spanish Tragedy and my response to it. Objectification of violence drives Hieronimo and informs this essay. In 1972, interpreting the arbor imagery and the rhetoric of reversal and self-cancellation in the play, I wrote, "Kyd is his father attacking himself in the womb he is in". After researching my suppressed family history, this peculiar sentence suggested to me unconscious knowledge of a run of murders in my family line, going back to the 1760 Long Cane Massacre of Irish settlers by Cherokee Indians in what is now South Carolina; continuing in the 1799 murder of Major William Love near what is now Harpe's Head, Kentucky; the suicide of my maternal grandfather in Philadelphia in 1931; and culminating in a Mafia-style execution of my father near Cleveland, Ohio in 1943.
\end{abstract}

\section{Introduction}

Researching family history can bring surprises, not all of them welcome. Having grown up away from my family and knowing very little about my antecedents, I decided to research these once the internet had made its contribution in the form of ancestry.com. This site brought me into contact with cousins I had not known I had, several of whom were also working on the ancestry.com site and had documented numerous folks. Among these new-found cousins, three were particularly helpful to me: Margaret Sims, a genealogist; Rhea Hunter, a family archivist; and Robert Stuart, a forensic investigator for the United States Veterans' Administration. Thanks to Robert Stuart, I discovered the story of the final moments of my maternal grandfather Orville Cecil, whose name I had not heard until 2010.

Before reaching the age of 65 , I did not know my mother's maiden name. When I learned that my mother had been born Mary Norma Cecil, I wondered about her dad, whose identity I discovered by looking up the record of her parents' marriage bond. The name Orville Cecil presented me with a mystery. Solving this mystery taught me more than my mother evidently thought I should know.

I grew up thinking my mother a baffling mystery; I now recognize her as a traumatized person with an unconscious errand that created a conduit for public expression of a history she probably never knew. I suspect I was analogizing and

1 Correspondence concerning this article should be addressed to Prof. Dianne Hunter. Email: dianne.hunter1@gmail.com

Language and Psychoanalysis, 2018, 7 (1), 23-34.

http://dx.doi.org/10.7565/landp.v7i1.1581 
voicing this unconscious history in my interpretive response to Kyd's play The Spanish Tragedy, which I first read in graduate school in the late 1960s.

My grandfather Orville Cecil Sr. shot his son, his wife, and himself when his daughter, my mother, was present on the scene, a week shy of her sixth birthday. My grandmother, hit in the left leg, and my uncle Robert Cecil, age 7, sitting on her lap and hit in the foot with the same bullet, survived. My grandfather-to-be, a 1913 U.S. Marine-Sharpshooter medalist (invalided out before World War I), went into an adjoining bedroom and fired a bullet through his brain.

Orville had married into a family with a 5-to-7-generation-distant history of being murder victims. See Figure 1, Catherine Montgomery->Esther Calhoun Love->Lucile Creason Cecil.

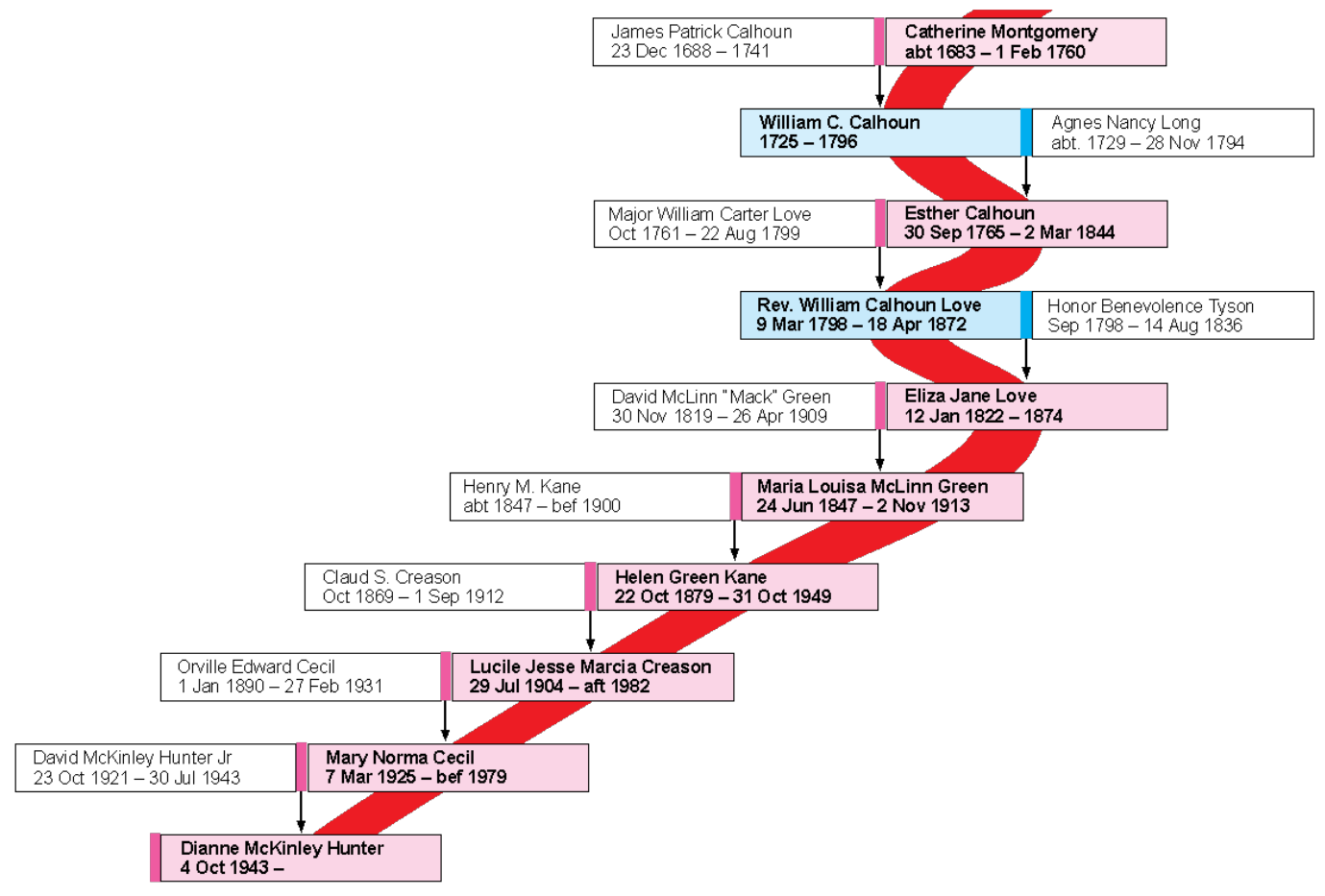

Figure 1

Genealogical chart by Margaret Sims showing the bloodline of Catherine Montgomery Calhoun in relation to Orville Cecil and Dianne Hunter.

Orville's self-inflicted murder, in the context of my maternal bloodline, seems to bear out George Henry Lewes's remark that murder can run in families, for, at the time of my birth, my widowed mother was an heir of sorts not only to her father's suicide but to a family massacre by Cherokee Indians and to the murder of an eighteenth-century victim of legendary killers who are memorialized by a place marker in Kentucky called "Harpes Head", named for the site of vigilante decapitation of one of the murderers. 
Mary Norma Cecil's 6xgreat grandmother Catherine Montgomery Calhoun (16841760), an Irish immigrant, was murdered with 22 members of her family at Long Cane, now Abbeville, South Carolina (Fischer, p. 646). Catherine's granddaughter Esther Calhoun Love (1765-1844) has carved into her tombstone, "My Husband Wm Love was Killed by the Harps", see Figure 2.

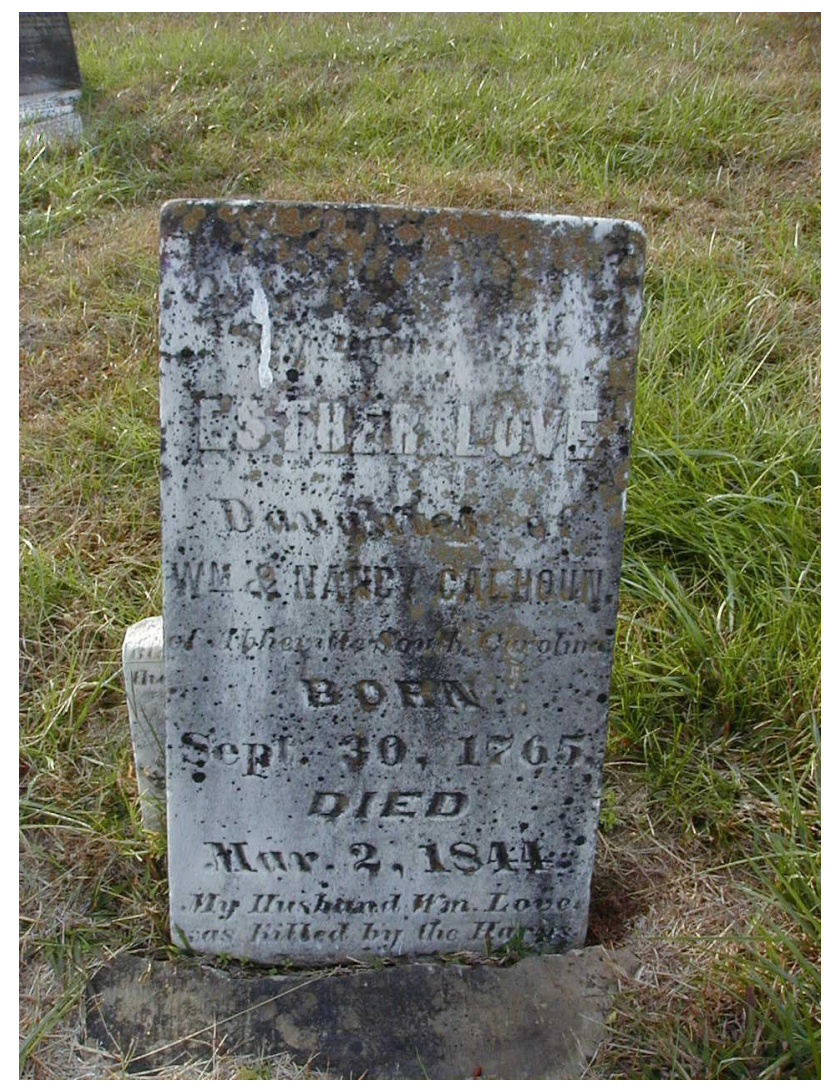

Figure 2

Tombstone of Esther Calhoun Love.

William Love (1761-1799), my 5xgreat grandfather, was murdered by America's first serial killers, the "Harpe Brothers" (who were actually Harpe cousins).

Esther's tombstone phrase "my Husband was Killed" is also true of the Loves' 4xgreat granddaughter, Norma Cecil Hunter, my mother, who became a bride, a widow, and a single mother as a teenager in 1942-43. Though I grew up knowing my father had died, my story was that he died during World War II, in France. I don't know how much of her family background my mother knew, if any; but she must have known her husband was killed when she was seven months pregnant. She never mentioned it to me.

Rhea, my Hunter family archivist, put me in touch with another cousin who was new to me as of 2012, a daughter of William Hunter, who reputedly sent his brother, David, my father, to a fatal appointment that was intended for William himself. Though I doubt the veracity of this family legend, I find the idea of a displaced object

Language and Psychoanalysis, 2018, 7 (1), 23-34. 
of violence in it significant to my argument about transmission of trauma. My father's death certificate states that he was shot in the face. The daughter of my uncle William told me that shooting in the face is a technique of the Mafia to keep its murder victims from being identified. William's daughter has the impression that my dad and hers were associates of the Cleveland Mafia, and that her dad had sent his younger brother, my dad, on an errand he could not perform himself, having absconded to California while owing a favor to associates in Cleveland. William, the absconding brother, therefore asked David to go in his place, inadvertently sending my dad to his death.

Unknown to me, aspects of this family history appear to have shaped my work as a psychoanalytic literary interpreter. When I wrote my Ph.D. dissertation in 1972, I read the violence and distancing in Thomas Kyd's Elizabethan metatheatrical dream play The Spanish Tragedy as rooted in the unconscious fantasy "Kyd is his father attacking himself in the womb he is in". I came up with this interpretation after studying the rhetorical patterns of reversal and self-cancellation in the play and its arbor imagery, which I took to signify the family tree.

The Spanish Tragedy raises images of the murder of two hapless warriors, Andrea and Horatio; plus a judicial murder by hanging; the suicide of Horatio's mother, Isabella, as she destroys the tree in her arbor where her son was hanged after being stabbed to death; the killing of two Iberian royal princes in a play within the play; suicide by the Spanish princess Bel-imperia in the play within the play; and the grieving fatherplaywright-judge Hieronimo's climactic suicide at the end of his play within the play, which has been presented in "sundry languages". When his audience fails to comprehend his actions, Hieronimo bites out his tongue. Commanded to write an explanation, he asks for a knife to sharpen his pen and then uses the knife to stab a member of his audience, his expressive frustration having given way to literal theatrical aggression.

In the overall Spanish Tragedy, the ghost Revenge stages a play for the murdered Andrea, who, now in the underworld, does not know that he was set up to be killed in war, a variation of the Biblical tale in II Samuel of King David having Uriah, the Hittite sent into the fiercest part of a battle and then abandoned so that David can marry Uriah's widow, Bathsheba. In Kyd's play, Andrea, in the role of the unwitting Uriah, is shown in a dream events that are happening on earth, where Andrea's friend Horatio takes over Andrea's former role as lover to the Spanish princess Bel-imperia. For her brother Lorenzo, both Horatio and Andrea are inconvenient obstacles to a dynastic plan to marry his sister to Balthazar, the Prince of Portugal. The two royal princes conspire to murder Horatio in the midst of a lovers' tryst. This they accomplish at night in the arbor of Horatio's father Hieronimo, who is the court playwright as well as a judge. Unable to approach the King to seek justice for his murdered son, Hieronimo, after much soliloquizing of grief and rage, instead stages a play in collusion with the twice-bereft Bel-imperia in which they kill Lorenzo and Balthazar before an audience of assembled Portuguese and Spanish royalty.

Figure 3 diagrams the way I see the complex metatheatrical dimensions of The Spanish Tragedy: 


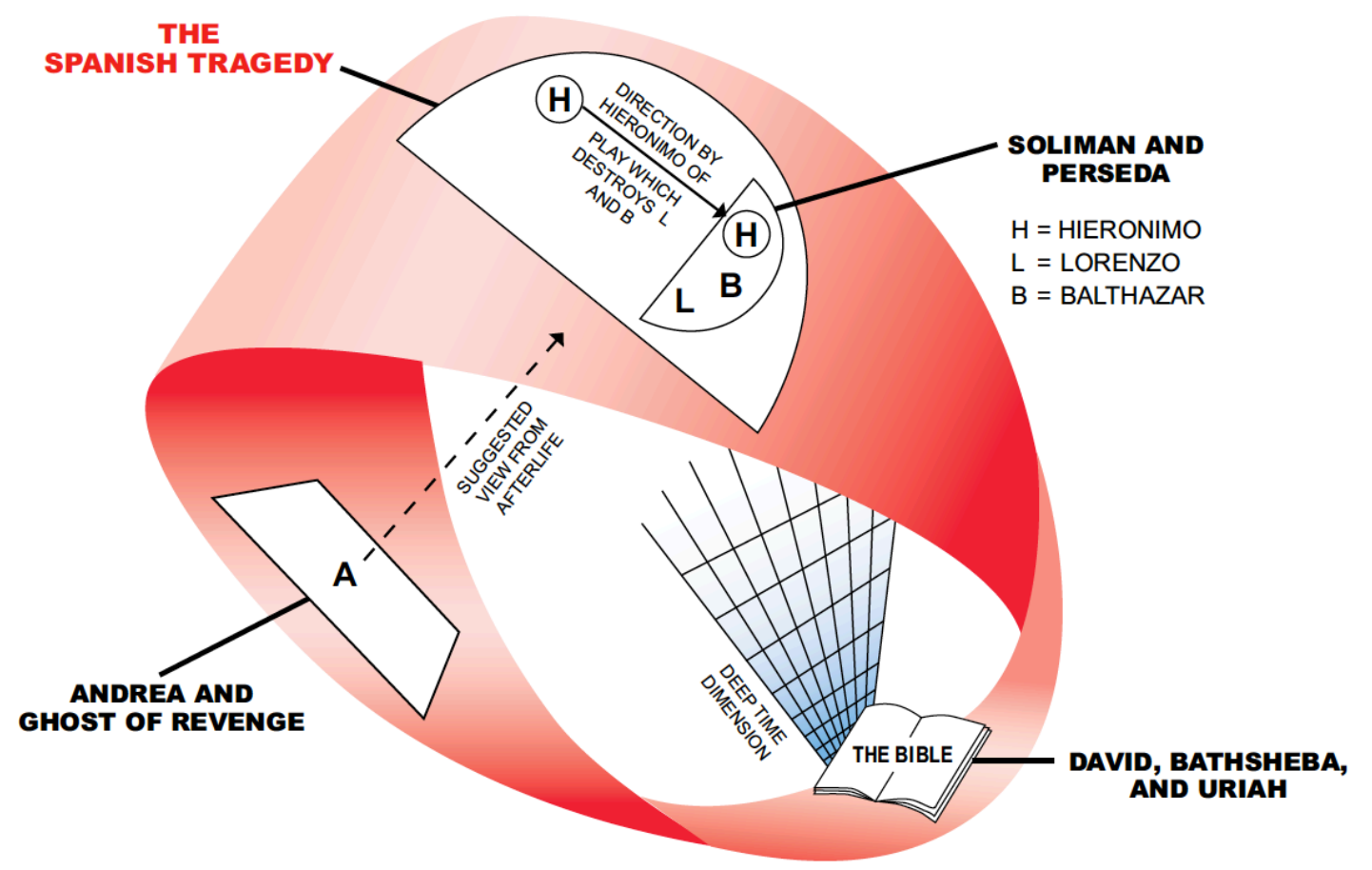

Figure 3

Mobius strip by Margaret Sims, showing metatheatrical dimensions of The Spanish Tragedy.

A key scene of the play shows Horatio's murder, committed in Hieronimo's garden, where his wife, Isabella, in frustration and rage, subsequently commits suicide upon destroying the family arbor where their son was hanged after being stabbed to death by Lorenzo and Balthazar. She declares, "And as I curse this tree from further fruit,/ So shall my womb be cursèd for his sake;/ And with this weapon will I wound the breast,/ The hapless breast, that gave Horatio suck". She stabs herself (IV.ii).

Isabella's suicide acts out in extremity the rhetorical pattern of reversal and selfcancellation informing Kyd's overall play, wherein the spectral personification Revenge tells the ghost of Andrea, "[E]re we go from hence,/ I'll turn their friendship into fell despite,/ Their love to mortal hate, their day to night,/ Their hope into despair, their peace to war,/ Their joys to pain, their bliss to misery" (I.v.5-10). Having been balanced as warring powers, afterwards "Spain is Portugal/ And Portugal is Spain" (I.v.17-18). Contemplating Lorenzo's scheme to murder Horatio, Balthazar says, "[I]t makes me glad and sad:/ Glad that I know the hinderer of my love; Sad, that I fear she hates me whom I love" (II.ii.111-113). During the arbor scene preceding his murder, when stabbing and hanging are to prove "fruits of love", Horatio meditates "On dangers past, and pleasures to ensue". In an aside, the spying Balthazar comments, "On pleasures past, and dangers to ensue". Bel-imperia asks Horatio, "What dangers and what pleasures dost thou mean?" He replies, "Dangers of war, and pleasures of our love", to which the spying Lorenzo chimes an aside, "Dangers of death, but pleasures none at all" (II.ii.25-31). In the play's most famous soliloquy, Hieronimo 
laments, "Oh eyes, no eyes, but fountains fraught with tears;/ Oh life, no life, but lively form of death;/ O world, no world" (III.ii.1-3). Displaying his son's corpse, Hieronimo says, "Here lay my hope, here my hope hath end:/ Here lay my heart, and here my heart was slain:/ Here lay my treasure, here my treasure lost:/ Here lay my bliss, and here my bliss bereft:/ But hope, heart, treasure/ joy, and bliss,/ All fled, failed, died, yea, decayed with this" (IV.iv.90-95), summing up his reversals of fortune.

When I originally responded to The Spanish Tragedy, I did not know that my father was murdered when I was two months from being born, but now I suspect that I was informed of this trauma without being aware of the transmission of knowledge. I regard this transmission as intergenerational because my mother's father killed himself when she was a small child, and she, I assume, must have experienced her husband's violent death as recurrence of the scene of gunshots she had experienced 12 years earlier. In addition, my paternal grandparents lived through the trauma of a murdered son who was heir to the legacy of Dr. William Forrester, stabbed to death by a patient in 1723; and my maternal grandmother lived through the death of her son-in-law in a way that must have recalled the trauma of being shot with her son and witnessing her husband's suicide in 1931. See Figure 4 for the William Forrester->David Hunter blood line.

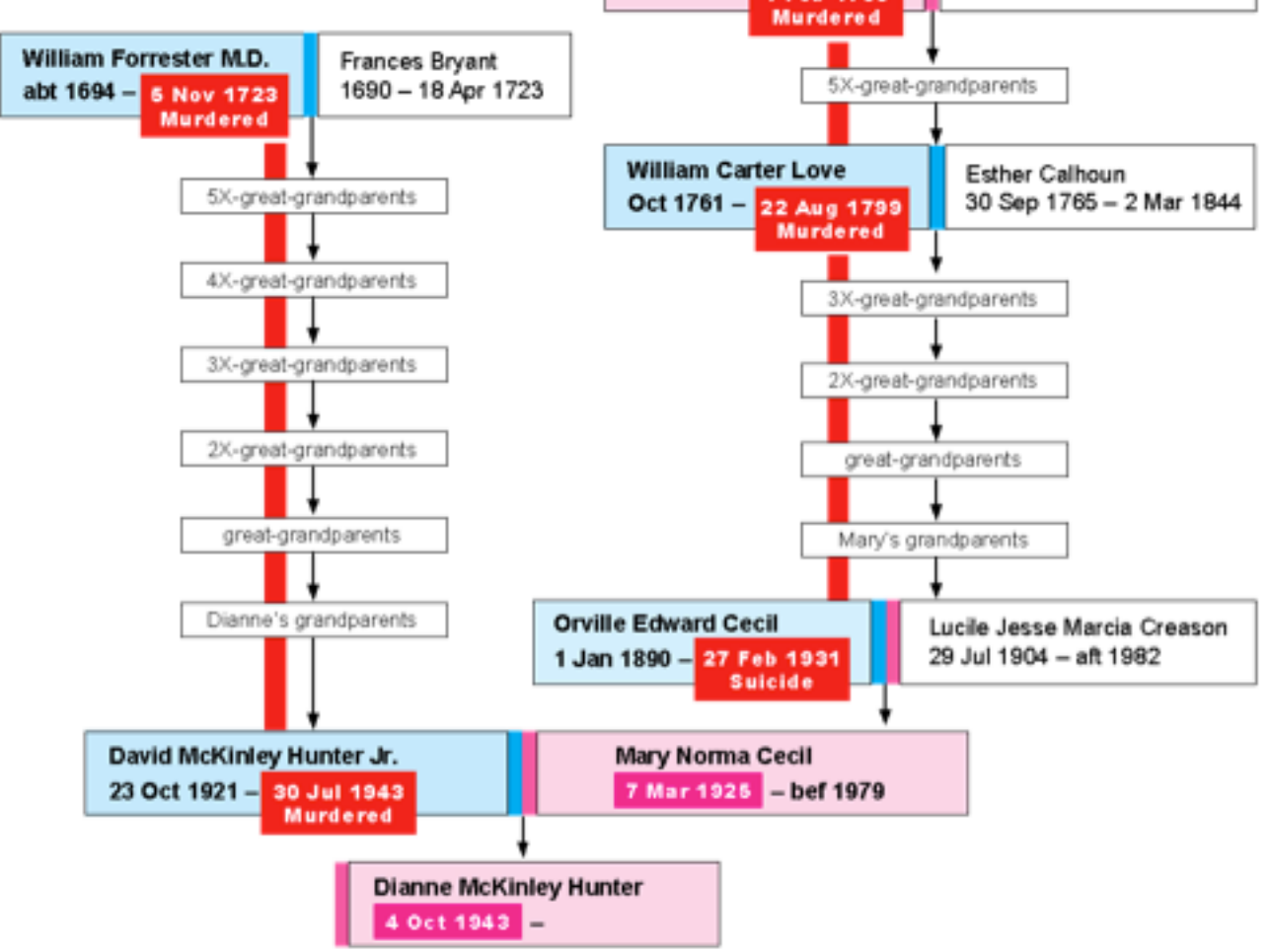

Figure 4

Genealogical chart by Margaret Sims, showing the double line of murders in the family history of Dianne Hunter.

Language and Psychoanalysis, 2018, 7 (1), 23-34. 
In sorting out this family history, I propose that a history of destructive aggression seeking objectification illuminates Hieronimo's fate and the metatheatrical structure of Kyd's revenge play, and that an object-relations explanation of transmission of family turbulence illuminates my response to these. In graduate school, I fixed on Kyd's play for a year of close reading, and regarded it as integral not only to my identity as an academic but to my psychic core, which at the time, I assumed revolved around primal scene fantasy. Now that I know that my father was murdered, and murdered two months before my birth, it is less the sexuality of this play than its complexity and its murders that interest me. The primal scene fantasy at the heart of the play I now see as the focus for traumatic transmission of a violent legacy reaching into deep time.

The emphasis on historical events that contemporary trauma studies bring to psychoanalysis as a field of work suggests the return of the real as a key theme in our cultural moment. After many films simulating the destruction of America, 9.11 actually happened. The memoir boom expresses a literary shift toward the real. In Kyd's play there is an otherworldly audience watching a play in which one of the players is a playwright who stages a play in which the barrier between playing and reality collapses. The actors die as part of the performance; the playwright kills a member of the audience and then himself.

In Hamlet it is curious that the protagonist and the traveling players happen to know a play, The Murder of Gonzago, that fits so exactly the poisonous circumstances of the king's hidden assassination. It is similarly suggestive of chronic recurrence and transmission of secret motives that Hieronimo's plot duplicates the Biblical story of the hapless Hittite. The plot of his play encrypts the story of Uriah, transposed to Turkey, where a knight of Rhodes was betrothed, and wedded to Perseda, "an Italian Dame, /Whose beauty ravished all that her beheld,/Especially the soul of Soliman" (IV.i.111-113). Bel-imperia acts as an avatar it seems of Perseda. Proserpine in the underworld gives his "doom" to Andrea and sends him back to earth accompanied by a phantom who stages a replay of his death in the form of Horatio's. This phantom personifying Revenge has knowledge beyond the temporal. The "soul" of Soliman implies transcendence of the temporal.

\section{Repetition and Witnessing}

Kyd wrote his play during the upsurge of English patriotism that accompanied the threat and defeat of the Spanish Armada in 1588. He has his playwright stage at the beginning of The Spanish Tragedy a celebration of three medieval English knights who defeated Saracen rulers in Spain and Portugal. The Ottoman Empire successfully expelled Knights of Rhodes from their stronghold in 1522, and in 1529, lay siege to Vienna. The failed Ottoman Siege against the Knights of Malta in 1565, one of the most famous events of the 16th century, demonstrated a new period of Spanish dominance of the Mediterranean. In the form of Hieronimo's historical allusions, the heritage of recurring, age-old Mediterranean-based wars echoes from the beginning to the end of Kyd's play.

Hieronimo has each of his players speak a different "unknown language"-Greek, Latin, Italian, and French. At the climax of his multilingual play, Hieronimo stages and relives his traumatic discovery of his murdered son, speaking in the past and

Language and Psychoanalysis, 2018, 7 (1), 23-34. 
present tense: "He shrieks: I heard, and yet, methinks, I hear" (IV.iv.107, my italics).

The analysis of The Spanish Tragedy David Willbern published in 1971 focuses on the psychology of revenge in this scene, on the way Hieronimo's vengeance repeats a crime in attempting to rectify it. Hieronimo has re-hanged his son as a prop for theatrical display. The avenger here identifies with the original aggressor insofar as Hieronimo is now inflicting on his royal audience the sight of murdered children, both his and theirs. Hieronimo can be seen to be attempting to master the traumatic loss of his son by repeating it with his role transformed from passive to active. He is doing this with witnesses.

Hieronimo "[Shows his dead son.]

See here my show, look on this spectacle:

... slaughtered as you see.

And grieved I (think you) at this spectacle?

Speak, Portuguese, whose loss resembles mine" (IV.iv.88-89, 112-115, my italics).

Figure 5, a woodcut showing the Arbor scene of Hieronimo's discovery of his son's body, depicts Hieronimo with a weapon similar to the sword held by one of the murderers. Hieronimo says, "[W]hat murd'rous spectacle is this? ...And in my bower, to lay the guilt on me" (II.v.9-11, my italics), psychologically aligning his trauma and ultimate role as avenger with the idea of duplicating the scene for which he seeks revenge. In staging his revenge, Hieronimo repeats the action of hanging Horatio and then tries to hang himself. This dramatizes how Hieronimo is both a subject and an object of destructive aggression.

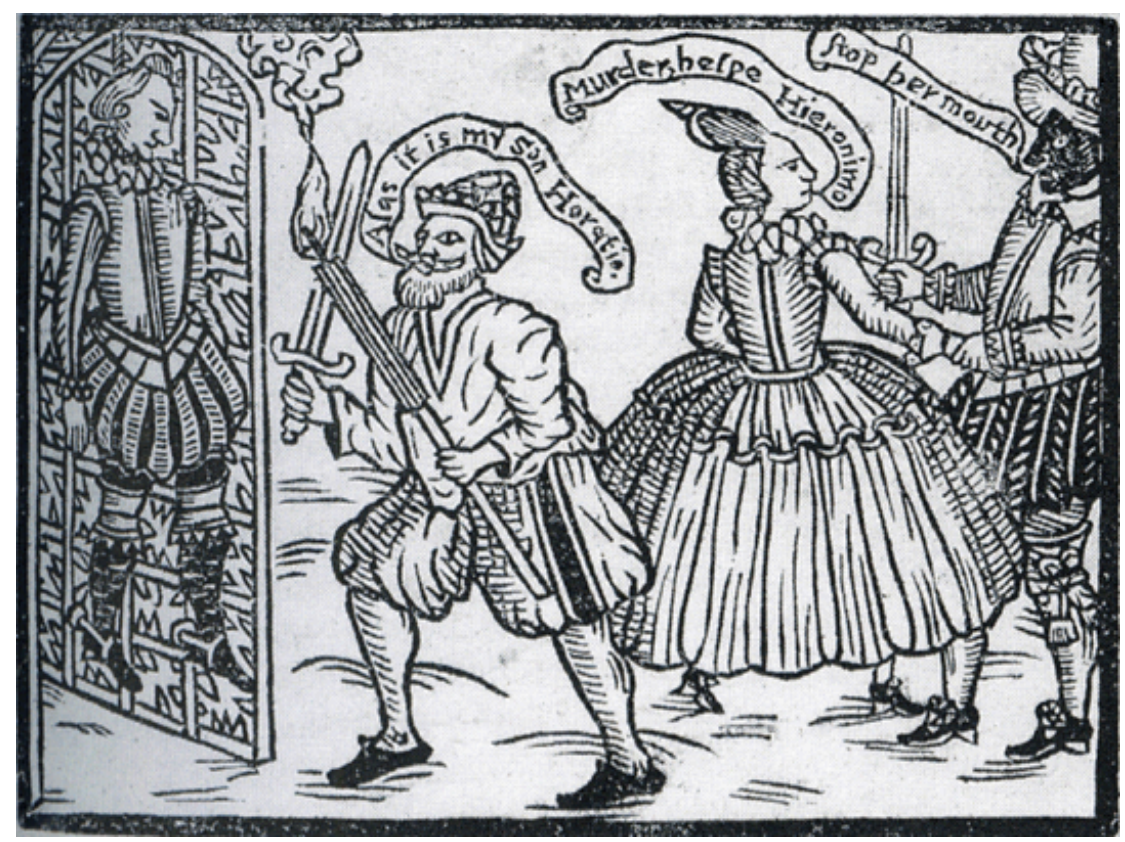

Figure 5

1615 Woodcut showing the Arbor crime scene Hieronimo revenges in his final play within the play.

Language and Psychoanalysis, 2018, 7 (1), 23-34.

http://dx.doi.org/10.7565/landp.v7i1.1581 
In dramatizing the stopping of time in the confrontation with death and horror, and in deploying sundry foreign languages to express horror's incomprehensibility, Kyd stages psychic marks of trauma that have been theorized by the psychoanalysts Francoise Davoine and Jean-Max Gaudillière, among others.

In addition, Hieronimo's infliction of visual shock- "slaughtered as you see"-not only repeats his own experience of finding his son murdered, it shows the trauma victim's need for a witness.

The Spanish Tragedy was the most iteratively performed drama of its day, suggesting on multiple levels how the survival of a baffling, violent event sets up the future of its representation: the trauma of finding his son hanging in the family arbor motivates Hieronimo's play, which is part of a multidimensional drama encrypting the secret assassination of his son's precursor Andrea, a version of the Biblical Uriah, the Hittite, who belonged to a culture that has all but disappeared from history. Hieronimo's allusions in his madness to Babel, Babylon, and the Crusades accumulate a deep history of violence concatenating in his revenge. Early in The Spanish Tragedy the villain Lorenzo declares, "Where words prevail not, violence prevails," a remark that ironically anticipates Hieronimo's trajectory as a seeker of justice. Reversing this remark anticipates the way a history of violence may seek objectification in words.

Theatrical suicide following theatrical aggression against the audience I now regard as a dramatic paradigm for comprehending the final acts of my maternal grandfather, who killed himself with his wounded family as his witnesses. Evidence of this trauma's intergenerational transmission is encrypted in a bizarre detail in one of the newspaper accounts of the death of my dad, who was found as a corpse in a ditch with his naturally-brown hair dyed red. My uncle Robert Cecil inherited his red hair from the man who shot him in the foot. When my maternal grandparents lost their first child Orville Cecil Jr. to pneumonia in 1923, my grandmother, who had been raised as a granddaughter of a prominent Baptist minister, converted to Catholicism because a priest her husband surprised her by bringing in to perform the last rites told her that if she ever wanted to see her baby again, she would have to become a Catholic herself. Six months pregnant at the time, my grandmother Lucile undertook catechism and prayed to God for another red-haired son. She believed God had answered her prayers when her next child, Robert, was born. So, I wonder, did my maternal grandmother convey to her daughter a red-hair fetish that contributed to the color of my dead dad's hair?

My mother survived the trauma of two dead redheads. Her silence on this subject drove me to find tools for analyzing complex plots, layers of consciousness, and hidden crimes. Commenting on Abraham and Torok's work on psychic encryption, Esther Rashkin remarks that we recapitulate, in our individual, ontogenetic work of being, the phylogeny of our infinitely regressive family sagas: "Every child's emergence as an individual is distinctive, constituted by repressions of uniquely charged pieces-of-the-mother, each bearing affects specifically related to the singular circumstances and psychic traumas of the mother's life. Moreover, since every mother is also the child of another mother, she must herself be understood as always already carrying the Language and Psychoanalysis, 2018, 7 (1), 23-34. http://dx.doi.org/10.7565/landp.v7i1.1581

Language and Psychoanalysis, 2018, 7 (1), 23-34. 
contents of another's unconscious" (Rashkin, p. 18). As Norma Cecil Hunter was carrying the turbulence of Esther Calhoun Love via Lucile Creason Cecil, I assume I became heir to that as well as to her father's suicide and her husband's murder and its ancestral antecedent.

The unconscious passing down of turbulence in a family's subjectivity can be understood via the object-relations theory the psychoanalyst Maurice Apprey uses to explain transgenerational transmission of destructive aggression. Commenting on Freud's theory that an instinct has a source, an aim, and an object, Apprey sees psychic turbulence as an obscured errand oscillating in a family's history between subjects and objects as it passes along through time. An ancestral source of turbulence recruits revenants hiding a secret in search of expression. Pressure accompanying reactivation, writes Apprey, can be slow and insidious. As the personification of Revenge, a phantom, remarks in The Spanish Tragedy, "in unquiet, quietness is feigned" (III.xv). A psyche inheriting turbulence cast undercover, says Apprey, "gathers itself in protest or in recalcitrant resignation and/or chooses the poison if perceived to be mandated for death. Finally, the figure of an object through which or through whom fulfillment can be achieved can in its turn store, suspend, defer or inject the toxin into yet another subject, a suitable figure that can provide an object home for the mediating subject" (2017). Objects recruited by phantoms act as revenants who may become advenants who bring the hidden source of turbulence into public space by objectifying it.

Voicing the history of violence informing Kyd's play objectifies psychic turbulence. Apprey's description of subject-object oscillation in the transmission of trauma through time illuminates the dramatic structure of Kyd's revenge tragedy and my personal analogizing in relation to it. William Empson was the first to write about how Kyd's play is cryptically informed by the Biblical story of Uriah's death in battle. Empson observes how Kyd's revenger-playwright assumes the role of Fate. In analyzing how Hieronimo in his madness acts in an inconsistent and roundabout way, Empson observes that this early play gives a more profound treatment of revenge than later ones (Empson, ed. Kaufmann, p. 68). If we see the spectating ghost of Andrea as a phantom harboring an unconscious secret along lines theorized by Abraham and Torok, we may take the falling in and out of sleep by personified Revenge in the play's framing dimension as dramatizing a latent force oscillating over time as it seeks an object for discharging destructive aggression. This allows us to understand Fate, that is, irrational causation, as ancestral haunting.

Considering Maurice Apprey's description of the way subjective turbulence seeks an object home on whom to displace violence transmitted from elsewhere, it is remarkable to me that the Hunter family's story of my dad's death as intended for his brother is apparently untrue. Though my dad was probably not killed in place of his brother, his family understood his death as a displacement. Similarly, the marriages in my family lines undertaken with counterparts carrying a history of being murder victims suggests the kind of recruitment of objects by mediating subjects transmitting turbulence such as Apprey describes in his psychiatric work.

Recapitulating from his perspective my maternal grandfather Orville's final moments, I think of his discharge from the U.S. Marines, deaf in one ear, presumably from gunshot. He was an orphan whose mother, Mary French, was herself orphaned at age

Language and Psychoanalysis, 2018, 7 (1), 23-34. 
four. Orville's older brother, his only sibling, poisoned himself to death in 1918, a month after their mother died in poverty. Within five years of these two deaths, Orville married Lucile and buried their first child. She divorced him in 1926, and became a Mrs. Driscoll in 1927. The 1930 U.S. Census lists Orville's son and daughter as Driscoll, and Lucile as a single mother. Less than a year later, Orville took revenge, violently joining his singular history to the history of murders in his wife's family line.

One Sunday morning in 2017, I drove to what I thought was the address in Philadelphia where Orville Cecil Sr. breathed his last, but I had reversed the house numbers given by the Philadelphia Inquirer newspaper account of his death and came to a place that did not look like the building I had found on Google maps. I drove around until I saw an apartment building that looked a bit like what I thought must be the place. When I checked my GPS, I realized this was a different street from the one I was seeking, so I drove back to what I took to be the address I wanted to photograph, and parked across from it. It was a quiet Sunday morning, with no one visible on this street. The address had an old, grayed wood, 7-foot pike-style fence in front and along its corner side, with a sign saying the equivalent of "This property is condemned". I could see piled-up trash and what looked to me like a crack house behind this fence. I went along the corner side and tried to photograph the house over the top of the fence. As I walked back to my car, I saw that a pale, thin man had pulled up on the sidewalk. He was astride a red motor scooter, and appeared to have been trying to open the passenger-side door of my car. He looked to be in his early 20 s, and wore a gray hoodie pulled up over his head. I asked him which house was "3929". He rolled glassy eyes and did not reply. As I got into the driver's seat of my car I saw a fat black young man puffing down the street in our direction. He arrived next to the pale man and peered into my windshield from the sidewalk. I waved and said, "Just leaving!" As I drove off, I thought, "What an ending for the story of Orville Cecil Sr.: "unknown woman from Connecticut found dead on Frankford Avenue in Philadelphia, thought to have been seeking drugs"'. No one would have known why I was there.

In sum, this essay presents two lines of argument: 1) an object-relations concept of the transmission of turbulence through Mediterranean and European history illuminates the metatheatrical and phantom structure of The Spanish Tragedy; 2) The concept of transgenerational transmission of family trauma illuminates my response to this play.

\section{References}

Abraham, N., \& Torok, M. (1987/1994). The shell and the kernel: Renewals of psychoanalysis. Chicago, IL: University of Chicago Press.

Apprey, M. (May 2017). Representing, theorizing and reconfiguring the concept of transgenerational haunting in order to facilitate healing. New Directions Conference, Washington Center for Psychoanalysis, Arlington, Virginia.

Davoine, F., \& Gaudillière, J.-M. (2004). History beyond trauma. New York, NY: Other Press.

Empson, W. (1956). The Spanish Tragedy, Nimbus III, 16-29. In R. J. Kaufmann (Ed.), Elizabethan drama: Modern essays in criticism (pp. 60-80). Oxford, UK: Oxford University Press.

Fischer, D. H. (1989). Albion's seed: Four British folkways in America. Oxford, UK: Oxford University Press. 
Gaudillière, J.-M., \& Davoine, F. (2004). History beyond trauma. New York, NY: Other Press.

Kaufmann, R. J. (1961). Elizabethan drama: Modern essays in criticism. New York, NY: Oxford University Press.

Kyd, T. (1590/1970). The Spanish tragedy. New York, NY: Hill and Wang.

Rashkin, E. (1992). Family secrets and the psychoanalysis of narrative. Princeton, NJ: Princeton University Press.

Torok, M. ([1987] 1994). The shell and the kernel: Renewals of psychoanalysis.

Chicago, IL: University of Chicago Press.

Weisgram, D. H. (1972). Violence and distance: A psychoanalytic study of the theatricalism of The Spanish tragedy. State University of New York, Buffalo.

Willbern, D. P. (1971). Thomas Kyd's The Spanish tragedy: Inverted vengeance. American Imago, 28, 247-267. 